\title{
Does $\beta$-glucan can have a protective role against oxidative stress in the experimental sepsis model in rats?
}

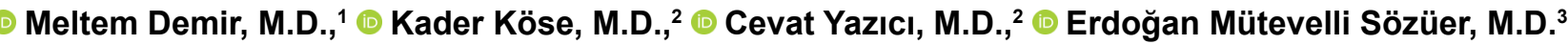

${ }^{1}$ Department of Medical Biochemistry, İstinye University Faculty of Medicine, İstanbul-Turkey

${ }^{2}$ Department of Medical Biochemistry, Erciyes University Faculty of Medicine, Kayseri-Turkey

${ }^{3}$ Department of General Surgery, Erciyes University Faculty of Medicine, Kayseri-Turkey

\begin{abstract}
BACKGROUND: Very high mortality rate in sepsis may be related to oxidative stress. This study was conducted on the rats to investigate the presence of oxidative stress and also the potential protective effects of the B-glucan in the intra-abdominal sepsis model formed by cecal ligation-perforation (CLP).

METHODS: In this study, 30 Male rats were equally divided into three groups as "Sham", "Sepsis" and "B-Glucan”. Only laparotomy was performed in the Sham group, and sepsis was induced by CLP in Sepsis and B-Glucan groups. Following CLP, a single dose of 4 $\mathrm{mg} \mathrm{B-glucan} / \mathrm{kg}$ was also intraperitoneally administered to the $\beta$-Glucan group. Blood and tissue (liver, lung and kidney) samples were taken from Sepsis and B-Glucan groups after sepsis development determined at the end of the 48th hour, also from the Sham group. The levels of myeloperoxidase (MPO) and advanced oxidation protein products (AOPP) were determined in plasma samples, and the malondialdehyde (MDA) was measured in plasma and tissues.
\end{abstract}

RESULTS: MPO and AOPP were higher in both the Sepsis and B-Glucan groups; however, plasma and tissue MDA levels were higher only in the Sepsis group than the Sham group $(p<0.05)$. However, when compared to the Sepsis group, all parameters measured, except kidney MDA, were significantly lower in the B-Glucan group $(p<0.05)$.

CONCLUSION: To our knowledge, this is the first study to investigate the AOPP levels in the CLP sepsis model, ROS produced by the reaction of MPO derived from neutrophils may form oxidative damage to the proteins, compared to the lipids, and B-glucan may be used as an alternative agent for sepsis treatment.

Keywords: Advanced oxidation protein products; B-Glucan; myeloperoxidase; reactive oxygen species; sepsis.

\section{INTRODUCTION}

Sepsis-induced multiple organ dysfunctions are the major cause of death in critical care units. ${ }^{[1-3]}$ The high mortality rate in sepsis mostly arises from gram-negative bacteria endotoxins, which cause secretion of cytokines by inducing the immune system, has also been suggested to be related to oxidative stress due to the generation of reactive oxygen species $(\mathrm{ROS})^{[4-6]}$ Despite the growing evidence that ROS is important during sepsis development, whether oxidative stress causes or propagates the pathogenesis of sepsis remains unclear. ${ }^{[5]}$ Thus, it represents a potential therapeutic target. ${ }^{[6]}$ ROS abla- tion for the treatment of sepsis could be useful in the clinical setting of sepsis-induced multiple organ failure. ${ }^{[4]}$ Clinical ${ }^{[7,8]}$ and experimental[ ${ }^{[4,9,10]}$ studies have demonstrated that B-glucan may be beneficial in the treatment of sepsis. Pretreatment with B-glucan in septic rats may have therapeutic potential to ameliorate clinical symptoms due to excessive production of proinflammatory cytokines during acute septic complications. ${ }^{\left[{ }^{11}\right]}$ A previous report from our team, ${ }^{[12]}$ investigating the protective effects of $\beta$-glucan on lung injury after cecal ligation and puncture (CLP) in rats, has been shown that ß-glucan treatment decreased lung damage according to both morphological and functional criteria in an experimental sepsis model.

Cite this article as: Demir M, Köse K, Yazıcı C, Sözüer EM. Does ß-glucan can have a protective role against oxidative stress in the experimental sepsis model in rats?. Ulus Travma Acil Cerrahi Derg 2020;26:657-662.

Address for correspondence: Meltem Demir, M.D.

İstinye Üniversitesi Tıp Fakültesi, Tıbbi Biyokimya Anabilim Dalı, İstanbul, Turkey

Tel: +90 850 - 2836000 E-mail: meldemir52@gmail.com

Ulus Travma Acil Cerrahi Derg 2020;26(5):657-662 DOI: 10.14744/tjtes.2019.79002 Submitted: 02.08.2019 Accepted: 29.12.2019 Online: 09.09.2020

Copyright 2020 Turkish Association of Trauma and Emergency Surgery 
In the present study, as a follow-up of the previous report, ${ }^{[12]}$ the experimental CLP sepsis model was used to demonstrate the increased ROS production by activated neutrophils, which leads to oxidative stress in sepsis, through the oxidations of lipids and proteins. Therefore, plasma Myeloperoxidase (MPO) activity as a neutrophil activation marker, and oxidative stress markers, such as plasma advanced oxidation protein products (AOPP) levels for protein oxidation, and malondialdehyde (MDA) levels for lipid peroxidation in both plasma and tissue samples obtained from liver, lung and kidney were determined in septic rats. In addition, the possible protective effects of B-glucan on these parameters were investigated and discussed its potential therapeutic effects on this rat model.

\section{MATERIALS AND METHODS}

The protocol of this study was approved by Erciyes University Animal Research Local Ethics Committee. This study was conducted on male Wistar albino rats grown at Hakan Çetinsaya Experimental and Clinical Research Center of University.

\section{Study Groups}

A total of 30 male rats, guaranteed to be free of particular pathogens and were acclimatized for one week before the experiments, weighing 250-300 g, were kept on the 12-hour light/dark cycle and at normal room temperature and moisture during this study. The rats, kept in standard wire cages and fed ad libitum with standard pellet chow and tap water, were randomly divided into three groups of 10 rats each to form "Sham", "Sepsis" and "ß-Glucan" groups.

\section{Study Design}

The rats were weighed before this study, and the doses of water-soluble B-glucan (Beta-D-glucan, Sigma, St. Louis, Mo., USA) and ketamine $\mathrm{HCl}$ (Ketalar ${ }^{\circledR}$, Parke-Davis, USA; $50 \mathrm{mg} /$ $\mathrm{mL}$ ) were adjusted to be applied per kilogram $(\mathrm{kg})$ of rat weight intraperitoneally (ip).

The rats were allowed to take only water for 12 hours before the operation. All surgical procedures were carried out under ip ketamine anesthesia $(50 \mathrm{mg} / \mathrm{kg})$ and in sterile conditions. In the Sham group, laparotomy was performed through a lower-midline incision, and the cecum was manipulated without being ligated or perforated. CLP procedure was applied to both Sepsis and B-Glucan groups, as previously described in detail 12 . A single dose of $4 \mathrm{mg} \beta$-glucan $/ \mathrm{kg}$ was also administered ip to the $B$-Glucan group, while two other groups were given equal volumes of saline. After surgery, the rats, which were received their cages and provided ad libitum fed, were followed up for 48 hours.

In the rats which were applied CLP with a preliminary study, sepsis was identified after 48 hours by the assessment of the cell content and morphology of bronchoalveolar lavage (BAL) fluid; ${ }^{[12]}$ therefore, blood samples were taken, and liver, lung and kidney tissues were removed from all groups under ketamine anesthesia at the end of 48 hours following laparotomy.

\section{Biochemical Analyses}

Plasma samples were kept at $-70^{\circ} \mathrm{C}$ until the determinations of MPO, MDA and AOPP levels. The tissue samples were washed with ice-cold saline, until the clearance of blood, and dried with filter paper; then, tissue portions were suspended and homogenized in ice-cold $0.15 \mathrm{~mol} / \mathrm{L}$ phosphate buffer, $\mathrm{pH}$ $7.4(10 \% \mathrm{wt} / \mathrm{vol})$. Homogenates were stored at $-70^{\circ} \mathrm{C}$ until MDA measurements.

Plasma MPO activity was conducted by the kinetic observation of o-dianisidine oxidation under the existence of $\mathrm{H}_{2} \mathrm{O}_{2}$ at $460 \mathrm{~nm}$. MPO activity was calculated using the molar extinction coefficient of $1.13 \times 10^{4} \mathrm{M}^{-1} \mathrm{~cm}^{-1}$ of oxidized o-dianisidine. ${ }^{[13]}$ The results were expressed as units of enzyme activity per liter of plasma (U/L).

AOPP levels were designated by the measurement of liberated triiodide ions at $340 \mathrm{~nm}$ during $\mathrm{KI}$ oxidization by cross-linking products created by chlorinated oxidants with plasma proteins, and AOPP levels were expressed as micromoles of chloramine-T equivalents per liter of plasma $(\mu \mathrm{mol} / \mathrm{L}){ }^{[14]}$

MDA levels in plasma and tissue homogenates were assessed by the spectrophotometrical method of Ohkawa et al., ${ }^{[15]}$ where in MDA couples to thiobarbituric acid to form pink chromogen compound, which has a maximum absorbance at $540 \mathrm{~nm}$. During measurement, plasma samples were used directly. Thawed samples of tissue homogenates (10\% wt/vol) were mixed by vortex, centrifuged at $20.000 \mathrm{~g}$ for $15 \mathrm{~min}$ at $+4^{\circ} \mathrm{C}$. The supernatants were used for MDA measurement on the same day. MDA levels were expressed as micromoles per liter $(\mu \mathrm{mol} / \mathrm{L})$ and nanomoles per gram of wet tissue weight $(\mathrm{nmol} / \mathrm{g})$, in plasma and tissue samples, respectively.

\section{Statistical Analyses}

The data were analyzed using Statistical Products and Service Solution package (SPSS, for Windows, 16 versions, Chicago, IL., USA). The normality of measured parameters was assessed using the Shapiro-Wilk test, and all data were determined to conform to a normal distribution. Comparison of the data was made by the analysis of variance (ANOVA) and post-ANOVA (Scheffe's procedure) tests among three groups. Furthermore, bivariate comparisons were made using Pearson correlation coefficients $(r)$ in the parameters of study groups. Data were presented as means \pm SD at the tables, and the difference was considered significant at $p<0.05$.

\section{RESULTS}

Since one rat of the Sepsis group died on the second postoperative day due to generalized peritonitis revealed by autopsy, 
Table I. MPO, AOPP and MDA values of the study groups

\begin{tabular}{|c|c|c|c|}
\hline \multirow[t]{2}{*}{ Parameters } & \multicolumn{3}{|c|}{ Study Groups } \\
\hline & Sham Group $(n=10)$ & Sepsis Group $(n=9)$ & B-Glucan Group $(n=10)$ \\
\hline Plasma MPO (U/L) & $65.4 \pm 17.9$ & $136.4 \pm 27.0^{*}$ & $98.5 \pm 27.0^{*}: \neq$ \\
\hline Plasma AOPP ( $\mu \mathrm{mol} / \mathrm{L})$ & $34.4 \pm 8.6$ & $|46.4 \pm 3| .8^{*}$ & $93.6 \pm 12.1^{* \neq \neq}$ \\
\hline Plasma MDA $(\mu \mathrm{mol} / \mathrm{L})$ & $1.8 \pm 0.5$ & $3.6 \pm 0.8^{*}$ & $1.9 \pm 0.4^{\ddagger}$ \\
\hline Lung MDA (nmol/g tissue) & $72.4 \pm 17.9$ & $118.8 \pm 23.6^{*}$ & $75.8 \pm 18.3^{\ddagger}$ \\
\hline Liver MDA (nmol/g tissue) & $64.5 \pm 18.3$ & $116.3 \pm 29.6^{*}$ & $76.6 \pm 16.8^{\ddagger}$ \\
\hline Kidney MDA (nmol/g tissue) & $81.6 \pm 17.1$ & $\mid 14.6 \pm 25.1^{*}$ & $93.6 \pm 20.9$ \\
\hline
\end{tabular}

Table 2. Significant correlations between parameters measured in the study groups

\begin{tabular}{|c|c|c|c|c|}
\hline \multirow[t]{2}{*}{ Biochemical parameters } & \multicolumn{2}{|c|}{ Sham Group $(n=10)$} & \multicolumn{2}{|c|}{ Sepsis Group $(n=9)$} \\
\hline & $\mathbf{r}$ & $\mathbf{p}$ & $\mathbf{r}$ & $\mathbf{p}$ \\
\hline Plasma: myeloperoxidase - AOPP & 0.752 & 0.012 & 0.797 & 0.01 \\
\hline Plasma malondialdehyde - Lung malondialdehyde & 0.856 & 0.001 & 0.900 & 0.001 \\
\hline Plasma malondialdehyde - Kidney malondialdehyde & - & - & 0.754 & 0.019 \\
\hline Lung malondialdehyde - Kidney malondialdehyde & 0.650 & 0.042 & 0.864 & 0.003 \\
\hline
\end{tabular}

$\mathrm{n}$ : Number of rats. AOPP: Advanced oxidation protein products.

this study was completed with 29 rats. No statistical difference was found among study groups concerning weight, both at the beginning and the end of this study $(p>0.05)$.

Plasma MPO activity and AOPP levels and MDA in plasma and tissue samples were shown in Table I. When compared to the Sham group, MPO and AOPP were found significantly increased in both the Sepsis and B-Glucan groups $(p<0.05)$; however, plasma and tissue MDA levels were higher only in Sepsis group $(p<0.05)$. When the Sepsis group was compared to the B-Glucan group, except kidney MDA, all parameters measured were significantly lower in the B-Glucan group $(p<0.05)$. There was a relative decrease in kidney MDA level, but it was not statistically significant $(p>0.05)$.

Only significant correlations among the parameters of the study groups are shown in Table 2. Plasma MPO activity was positively correlated with AOPP levels, and there were significantly positive correlations between plasma and lung MDA, and also lung - kidney MDA levels in both the Sham and the Sepsis groups $(p<005)$.

\section{DISCUSSION}

In the present study, plasma AOPP and MPO levels were found to be higher in septic rats. To our knowledge, there has been no study measuring plasma AOPP in experimental sepsis by inducing CLP. On the other hand, clinical studies, and also experimental studies in different animal species, and different types of sepsis models except CLP, have been shown to increase in plasma AOPP and MPO levels. ${ }^{[16]}$ Selmeci et al. has suggested that plasma AOPP measurement is especially suitable for monitoring oxidative stress in critically ill patients even at daily intervals since AOPP exhibited rapid responses in both directions. Additionally, increased AOPP levels have been reported in critically ill patients, induced by the overproduction of ROS and the subsequent depletion of the antioxidant endogenous stores. In experimental studies, plasma AOPP levels were higher in dogs infected with Rangelia vitalii, ${ }^{[17]}$ and a significant increase in plasma; AOPP levels was also measured in the rats inoculated with infective blood by Trypanosoma evansi. ${ }^{[18]}$

The finding of high AOPP levels in septic rats can be explained in the way that chlorinated oxidants, $\mathrm{HOCl}$ and chloramines are only produced by phagocytic cells in vivo, which migrate to lungs that cause the formation AOPP. Supporting this view, since chloramines have been reported to increase membrane permeability, ${ }^{[19]}$ these oxidants may be assumed to pass from tissue to plasma. In an experimental obstructive jaundice model induced by choleduct ligation, ${ }^{[20]}$ and in mediastinitis model by methicillin-resistant Staphylococcus aureus, ${ }^{[21]}$ serum MPO activity was found to be higher in the rats. Mühl 
et al. ${ }^{[22]}$ and Kothari et al. ${ }^{[23]}$ found increased plasma MPO levels in patients with sepsis; and suggested that neutrophil activation occurring during inflammation and sepsis could be detected by plasma MPO released into the blood, which may be a good biomarker of the neutrophil proliferation and severity of inflammation (Fig. I). ${ }^{[23]}$

MDA levels in liver, lung and kidney tissues, and also in plasma were found higher and the correlations between MDA levels in plasma, lung and kidney were also obtained in septic rats in the present study, indicating the sepsis as a cause of oxidative damage in the liver, kidney and lung tissues; demonstrated by the increased lipid peroxidation. Increased MDA levels in the liver, ${ }^{[4,9-11]}$ lung, ${ }^{[4,9,10,24-27]}$ and kidney tissues, ${ }^{[4,9,10,24,26]}$ and also in plasma ${ }^{[4,9,10]}$ were reported in CLP-induced septic rats. Furthermore, Koksal et al. ${ }^{[10]}$ reported that plasma MDA was correlated to MDA in liver, lung, and kidney in septic rats induced by CLP; and suggested that increased oxidative stress in tissues in parallel with plasma may be important mechanisms due to the output of free radicals.

Furthermore, in the present study, for the first time, decreases in plasma MPO and AOPP values with B-glucan administration were found to be statistically significant concerning the efficacy of treatment. These findings may suggest that B-glucan suppresses the severity of sepsis, and regarding these results, inflammation following induction of sepsis was decreased by B-glucan. Obviously, lower neutrophil accumulation will result in lower tissue inflammation. As seen in the first part of the present study, ${ }^{[12]}$ lower neutrophil and higher monocyte percentages were observed by B-glucan administration, compared to septic rats. When considering decreased percentages of neutrophils, these findings may be explained as the B-glucan that may prevent both inflammation and also MPO release from activated phagocytic cells to plasma. Additionally, the formation of chloramines by MPO mediated reactions, which may oxidize proteins, may be captured by ß-glucan and in this manner; the oxidative damage secondary to respiratory burst may be partially prevented.

There are contrasting views about the relationship between MDA, oxidative stress and sepsis. Namely, Lorente et al. ${ }^{[28]}$ reported that increased serum MDA levels were associated

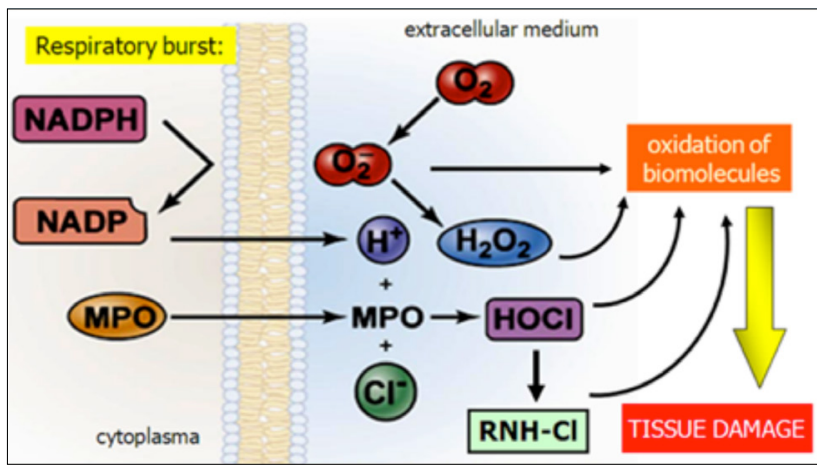

Figure 1. Respiratory burst and formation of chloramines. with severity and mortality in septic patients, irrespective of site of the infection, type of micro-organism, or dysfunctional organ system, suggesting that lipid peroxidation was attributable to the general host response rather than a pathogen- or organ-specific reaction. Otherwise, the considerable overlap between sepsis survivors and non-survivors limits the utility of MDA in clinical practice. ${ }^{[l]}$ According to Weiss and Deutschman, ${ }^{[6]}$ lipid peroxidation is not specific to sepsis and may be affected by comorbid conditions, diet, and lifestyle behaviors, and also its shorter half-life and the lack of stability, and the use of non-specific/non-sensitive methods affect the reliability of the MDA results. ${ }^{[6,29]}$ Therefore, further study is required to validate the utility of MDA as a prognostic biomarker in sepsis. ${ }^{[6]}$ On the other hand, during severe sepsis or organ failure, the body response fails to protect itself. An intense study of oxygen radical-mediated mechanisms may lead to improved therapies in sepsis treatment. ${ }^{[5]}$ Although the antioxidant therapies in sepsis remains an attractive but unproven strategy; ${ }^{[6]}$ the use of biological mediators or pharmacological agents with antioxidant properties is gradually increasing to strengthen the endogenous defense system in many diseases involving oxidative stress in their pathogenesis. The studies have focused on the B-glucan molecule because of the beneficial effects on the immune system and the lack of toxic or adverse effects. ${ }^{[2]}$

Although major discrepancies exist, several mechanisms are proposed for the protective effects of B-glucan treatment, some of them are related to antioxidant capacity and free-radical scavenger activity, and anti-inflammatory properties of the molecule. ${ }^{[2,4,30]}$ Systemic administration of B-glucans has been shown to enhance host protection against infections in humans and animal models, such as sepsis and associated organ injury. Clinical studies have shown that glucan therapy can reduce hospitalization time, post-operative infection and mortality rates in high-risk patients undergoing major thoracic or abdominal surgery ${ }^{[7,8]}$ and suggested that intake of glucans in trauma surgical patients will increase the chance of survival via decreasing the frequencies of septic complications. Additionally, in a clinical ex-vivo study, it has been shown that B-glucan could protect an endothelial monolayer from damage that arises from neutrophils obtained from septic patients exert a dramatic compromise of endothelial barrier integrity. ${ }^{[31]}$ Similarly, when investigated in vitro effects of ß-glucan on oxidative stress by lipopolysaccharide associated with oxidative damages of human blood platelets; TBARS, protein carbonyl levels and nitration of tyrosine residues in proteins of platelets were found to be lower in the presence of B-glucan. ${ }^{[32]}$ These findings are also in accordance with the present study that B-glucan administration was associated with significantly reversing the high MDA levels in tissues and plasma of a rat model where sepsis was induced by CLP.

In conclusion, although sepsis cannot be simplified to ROS pathology alone, in this first study in which AOPP levels in sepsis model are investigated; it may be suggested that the 
oxidants produced by MPO derived from neutrophils are more likely to cause oxidative damage to proteins than lipids, and B-glucan with anti-inflammatory and antioxidant effects may be a promising candidate with further clinical and experimental trials for sepsis therapy.

Ethics Committee Approval: Approved by the local ethics committee.

Peer-review: Internally peer-reviewed.

Authorship Contributions: Concept: M.D., K.K., C.Y., E.M.S.; Design: M.D., K.K., C.Y.; Supervision: M.D., K.K.; Fundings: M.D., K.K.; Materials: M.D., K.K., C.Y., E.M.S; Data: M.D., K.K., C.Y., E.M.S; Analysis: M.D., K.K., C.Y.; Literature search: M.D., K.K., C.Y., E.M.S; Writing: M.D., K.K.; Critical revision: M.D., K.K., C.Y., E.M.S.

\section{Conflict of Interest: None declared.}

Financial Disclosure: The authors declared that this study has received no financial support.

\section{REFERENCES}

1. Samraj RS, Zingarelli B, Wong HR. Role of biomarkers in sepsis care. Shock 2013;40:358-65. [CrossRef]

2. Ercan $\mathrm{M}, \mathrm{O} z$ demir $\mathrm{S}$. The contribution to studies of the effect of $\beta$-glucan on plasma viscosity in rat sepsis model. Med Sci Discover 2015;2:14853. [CrossRef]

3. Liu VX, Fielding-Singh V, Greene JD, Baker JM, Iwashyna TJ, Bhattacharya J, et al. The Timing of Early Antibiotics and Hospital Mortality in Sepsis. Am J Respir Crit Care Med 2017;196:856-63. [CrossRef]

4. Sener G, Toklu H, Ercan F, Erkanli G. Protective effect of beta-glucan against oxidative organ injury in a rat model of sepsis. Int Immunopharmacol 2005;5:1387-96. [CrossRef]

5. Crimi E, Sica V, Williams-Ignarro S, Zhang H, Slutsky AS, Ignarro LJ, et al. The role of oxidative stress in adult critical care. Free Radic Biol Med 2006; 40:398-406. [CrossRef]

6. Weiss SL, Deutschman CS. Elevated malondialdehyde levels in sepsis something to 'stress' about?. Crit Care 2014;18:125. [CrossRef]

7. Babineau TJ, Hackford A, Kenler A, Bistrian B, Forse RA, Fairchild PG, et al. A phase II multicenter, double-blind, randomized, placebo-controlled study of three dosages of an immunomodulator (PGG-glucan) in high-risk surgical patients. Arch Surg 1994;129:1204-10. [CrossRef]

8. Dellinger EP, Babineau TJ, Bleicher P, Kaiser AB, Seibert GB, Postier $R G$, et al. Effect of PGG-glucan on the rate of serious postoperative infection or death observed after high-risk gastrointestinal operations. Betafectin Gastrointestinal Study Group. Arch Surg 1999;134:977-83.

9. Ritter C, Andrades M, Frota Júnior ML,Bonatto F, Pinho RA, Polydoro $\mathrm{M}$, et al. Oxidative parameters and mortality in sepsis induced by cecal ligation and perforation. Intensive Care Med 2003;29:1782-9. [CrossRef]

10. Koksal GM, Sayilgan C, Aydin S, Oz H, Uzun H. Correlation of plas$\mathrm{ma}$ and tissue oxidative stresses in intra-abdominal sepsis. J Surg Res 2004;122:180-3. [CrossRef]

11. Senoglu N, Yuzbasioglu MF, Aral M, Ezberci M, Kurutas EB, Bulbuloglu E, et al. Protective effects of $\mathrm{N}$-acetylcysteine and beta-glucan pretreatment on oxidative stress in cecal ligation and puncture model of sepsis. J Invest Surg 2008;21:237-43. [CrossRef]

12. Babayigit H, Kucuk C, Sozuer E, Yazici C, Kose K, Akgun H. Protective effect of beta-glucan on lung injury after cecal ligation and puncture in rats. Intensive Care Med 2005;31:865-70. [CrossRef]

13. Bradley PP, Priebat DA, Christensen RD, Rothstein G. Measurement of cutaneous inflammation: estimation of neutrophil content with an enzyme marker. J Invest Dermatol 1982;78:206-9. [CrossRef]

14. Witko-Sarsat V, Friedlander M, Capeillère-Blandin C, Nguyen-Khoa T, Nguyen AT, Zingraff J, et al. Advanced oxidation protein products as a novel marker of oxidative stress in uremia. Kidney Int 1996;49:1304-13.

15. Ohkawa $\mathrm{H}$, Ohishi N, Yagi K. Assay for lipid peroxides in animal tissues by thiobarbituric acid reaction. Anal Biochem 1979;95:351-8. [CrossRef]

16. Selmeci L, Seres L, Antal M, Lukács J, Regöly-Mérei A, Acsády G. Advanced oxidation protein products (AOPP) for monitoring oxidative stress in critically ill patients: a simple, fast and inexpensive automated technique. Clin Chem Lab Med 2005;43:294-7. [CrossRef]

17. França RT, Da Silva AS, Costa MM, Paim FC, Paim CB, Thomé GR, et al. Relationship between oxidative stress and clinical-pathological aspects in dogs experimentally infected with Rangelia vitalii. Res Vet Sci 2012;93:1309-13. [CrossRef]

18. Da Silva AS, Paim FC, Santos RC, Sangoi MB, Moresco RN, Lopes ST, Jaques JA, Baldissarelli J, Morsch VM, Monteiro SG. Nitric oxide level, protein oxidation and antioxidant enzymes in rats infected by Trypanosoma evansi. Exp Parasitol 2012;132:166-70. [CrossRef]

19. Ogino T, Packer L, Maguire JJ. Neutrophil antioxidant capacity during the respiratory burst: loss of glutathione induced by chloramines. Free Radic Biol Med 1997;23:445-52. [CrossRef]

20. Erkol H, Kahramansoy N, Kordon Ö, Büyükaşık O, Serin E, Kükner A. Effect of beta-glucan in lung damage secondary to experimental obstructive jaundice. Turk J Gastroenterol 2012;23:38-45. [CrossRef]

21. Sacar S, Sacar M, Aybek H, Turgut H, Onem G, Cevahir N, et al. Comparison of the therapeutic efficacy of linezolid and vancomycin and correlation of serum and tissue malondialdehyde and myeloperoxidase in an experimental mediastinitis model.J Surg Res 2009;152:89-95. [CrossRef]

22. Mühl D, Woth G, Drenkovics L, Varga A, Ghosh S, Csontos C, et al. Comparison of oxidative stress $\&$ leukocyte activation in patients with severe sepsis \& burn injury. Indian J Med Res 2011;134:69-78.

23. Kothari N, Keshari RS, Bogra J, Kohli M, Abbas H, Malik A, et al. Increased myeloperoxidase enzyme activity in plasma is an indicator of inflammation and onset of sepsis. J Crit Care 2011;26:435.e1-7. [CrossRef]

24. Andrades M, Ritter C, Moreira JC, Dal-Pizzol F. Oxidative parameters differences during non-lethal and lethal sepsis development. J Surg Res 2005;125:68-72. [CrossRef]

25. Ozturk E, Demirbilek S, Begec Z, Surucu M, Fadillioglu E, Kirimlioglu $\mathrm{H}$, et al. Does leflunomide attenuate the sepsis-induced acute lung injury? Pediatr Surg Int 2008;24:899-905. [CrossRef]

26. Andrades M, Ritter C, de Oliveira MR, Streck EL, Fonseca Moreira JC, Dal-Pizzol F. Antioxidant treatment reverses organ failure in rat model of sepsis: role of antioxidant enzymes imbalance, neutrophil infiltration, and oxidative stress. J Surg Res 2011;167:e307-13. [CrossRef]

27. Zolali E, Hamishehkar H, Maleki-Dizaji N, Majidi Zolbanin N, Ghavi$\mathrm{mi} \mathrm{H}$, Kouhsoltani M, et al. Selenium effect on oxidative stress factors in septic rats. Adv Pharm Bull 2014;4: 289-93.

28. Lorente L, Martín MM, Abreu-González P, Domínguez-Rodriguez A, Labarta L, Díaz C, et al. Sustained high serum malondialdehyde levels are associated with severity and mortality in septic patients. Crit Care 2013;17:R290. [CrossRef]

29. Dalle-Donne I, Rossi R, Colombo R, Giustarini D, Milzani A. Biomarkers of oxidative damage in human disease. Clin Chem 2006;52:601-23.

30. Du B, Lin C, Bian Z, Xu B. An insight into anti-inflammatory effects of fungal beta-glucans. Trends Food Sci Technol 2015;41:49-59. [CrossRef]

31. Fox ED, Heffernan DS, Cioffi WG, Reichner JS. Neutrophils from critically ill septic patients mediate profound loss of endothelial barrier integrity Crit Care 2013;7-17:R226. [CrossRef]

32. Saluk J, Bijak M, Ponczek MB, Nowak P, Wachowicz B. $(1 \rightarrow 3)-\beta$-D-Glucan reduces the damages caused by reactive oxygen species induced in human platelets by lipopolysaccharides. Carbohydr Polym 2013;97:71624. [CrossRef] 
DENEYSEL ÇALIŞMA - ÖZET

\section{ß-glukan, sıçanlarda deneysel sepsis modelinde oksidatif strese karşı koruyucu rol oynayabilir mi? \\ Dr. Meltem Demir, ${ }^{1}$ Dr. Kader Köse, ${ }^{2}$ Dr. Cevat Yazıcı, ${ }^{2}$ Dr. Erdoğan Mütevelli Sözüer ${ }^{3}$}

${ }^{1}$ İstinye Üniversitesi Tıp Fakültesi, Tıbbi Biyokimya Anabilim Dalı, İstanbul

${ }^{2}$ Erciyes Üniversitesi Tıp Fakültesi, Tıbbi Biyokimya Anabilim Dalı, Kayseri

${ }^{3}$ Erciyes Üniversitesi Tıp Fakültesi, Genel Cerrahi Anabilim Dalı, Kayseri

AMAÇ: Sepsiste çok yüksek mortalite oranı oksidatif stres ile ilişkili olabilir. Bu çalışma fareler üzerinde, çekal ligasyon-perforasyon (CLP) ile oluşturulan karıniçi sepsis modelinde oksidatif stresin varlı̆ı̆ı ve ayrıca ß-glukanın potansiyel koruyucu etkisini araştırmak için yapılmıştır.

GEREÇ VE YÖNTEM: Otuz erkek sıçan eşit olarak "Sham", "Sepsis" ve "B-Glukan" olarak üç gruba ayrıldı. Sham grubunda sadece laparotomi yapıldı, Sepsis ve B-Glukan gruplarında CLP ile sepsis oluşturuldu. B-Glukan grubuna CLP'yi takiben intraperitonal olarak tek bir doz 4 mg B-glukan/ $\mathrm{kg}$ verildi. Sepsis gelişiminden sonra 48. saatin sonunda Sepsis ve $\beta$-Glukan gruplarından ve Sham grubundan kan ve doku (karaciğer, akciğer ve böbrek) örnekleri alındı. Plazma örneklerinde miyeloperoksidaz (MPO) ve ileri oksidasyon protein ürünleri (AOPP) seviyeleri belirlendi ve plazma ve dokularda malondialdehit (MDA) ölçüldü.

BULGULAR: MPO ve AOPP, Sepsis ve B-Glukan gruplarında daha yüksekti; ancak plazma ve doku MDA düzeyleri sadece Sepsis grubunda Sham grubundan daha yüksekti $(p<0.05)$. Bununla birlikte, Sepsis grubuyla karşılaştırıldığında, böbrek MDA değeri hariç ölçülen tüm parametreler, B-Glukan grubunda anlamlı olarak daha düşüktü $(p<0.05)$.

TARTIŞMA: CLP sepsis modelinde AOPP düzeylerini araştırmak için yapılan bu ilk çalışada; nötrofillerden salgılanan MPO reaksiyonu ile üretilen ROS, lipitlere kıyasla proteinlerde oksidatif hasar oluşturabilir ve ß-glukan, sepsis tedavisi için alternatif bir ajan olarak kullanılabilir. Anahtar sözcükler: B-Glukan; ileri oksidasyon protein ürünleri; miyeloperoksidaz; reaktif oksijen türleri; sepsis.

Ulus Travma Acil Cerrahi Derg 2020;26(5):657-662 doi: 10.14744/tjtes.2019.79002 